\title{
Australia Government Response to COVID-19: Coordination and the Effectivity of Policy
}

\author{
Respon Pemerintah Australia terhadap Pandemi \\ COVID-19: Koordinasi sebagai Kunci Efektivitas \\ Kebijakan
}

\author{
Fauziah R. Mayangsari \\ Master of Asian and Pacific Studies Candidate Australian \\ National University
}

\begin{abstract}
ABSTRAK
Artikel ini mendeskripsikan respon pemerintah Australia terhadap pandemi COVID-19. ini Respon kebijakan pemerintah yang menjadi fokus adalah pengelolaan risiko di tiga sektor utama: kesehatan masyarakat, sistem kesehatan nasional, dan keberlangsungan perekonomian negara. Artikel ini kemudian menjelaskan bagaimana Australia dianggap sebagai salah satu contoh negara yang sukses dalam menangani pandemi COVID-19. Kebijakan untuk menutup perbatasan sejak dini dan penyusunan kebijakan terkoordinasi yang berdasar saran para ahli merupakan beberapa kunci kesuksesan Australia. Selain itu, kepatuhan masyarakat turut mendukung keberhasilan implementasi dari kebijakan pemerintahan. Namun, kepatuhan penduduk Australia merupakan hasil dari rasa percaya terhadap kemampuan pemerintah untuk menangani krisis. Berbagai faktor tersebut membuat Australia berhasil melandaikan kurva COVID-19 dalam waktu kurang dari enam bulan. Walaupun masih cukup dini untuk mengidentifikasi pelajaran yang bisa diambil dari Australia, namun dapat dikatakan bahwa ditengah pandemi dan krisis, pemerintah harus bekerja bersama dengan masyarakat agar kebijakan yang telah disusun dapat diimplementasikan dengan baik.
\end{abstract}

Kata-kata kunci: COVID-19; respon pandemi; Australia, Koordinasi, Strategi

This article describes the Australian Government's responses to the COVID-19 pandemic. The focus is on the policy responses to mitigate the risk in three main sectors: people's health, national health system, and economic livelihoods. It discusses how Australia's response to the COVID-19 pandemic is among the few successful cases in the world. Australia's early border closure and coordinated policy measures with the experts are among the key behind Australia's success. Besides, Australian public compliance further supports the implementation of government policy. Such compliance is the result of people's trust in the Government's capability to tackle the crisis. As a consequence, Australia has succeeded in flattening the curve within less than six months. Although it is relatively early to identify the lessons learned from Australia, it is safe to say that during pandemic and crisis, in order to make the policy works, the Government needs to work together with the public.

Keywords: COVID-19, pandemic response, Australia, Coordination, Strategy 
Australia merupakan salah satu negara yang dianggap sukses menangani virus SARS-COV-2 atau yang lebih dikenal dengan COVID-19. Tercatat hingga akhir Juni 2020, terdapat 7,834 total kasus di Australia dengan angka kematian sebesar 104 jiwa dan jumlah kesembuhan 7,037 orang (Department of Health 2020a). Jika dibandingkan dengan total populasi, angka kematian akibat COVID-19 di Australia hanya berkisar 1.46\%. Angka tersebut cukup baik dibandingkan negara lain dan menunjukkan bahwa dalam waktu kurang lebih enam bulan ${ }^{1}$, Australia mampu menekan angka kematian dan persebaran virus. Meskipun tidak berjalan mulus, secara umum dapat dikatakan bahwa kebijakan pemerintah Australia cukup efektif merespons pandemi COVID-19.

Pada artikel ini, penulis mengkaji strategi yang diterapkan oleh Australia sebagai respon terhadap pandemi COVID-19. Sebagai catatan, periode yang menjadi fokus artikel ini adalah sebelum terjadinya lonjakan kasus di Victoria, yakni bulan Januari hingga Juni. ${ }^{2}$ Dua hal yang kemudian menjadi kunci dari keberhasilan pemerintah Australia adalah: (1) keputusan untuk menutup perbatasaninternasionaldanlokal,(2)koordinasiantarpemerintah pusat dan negara bagian menghasilkan instruksi yang tegas dan jelas bagi masyarakat. Untuk menjelaskan efektivitas pemerintah Australia dalam menangani pandemi COVID-19, artikel ini dibagi dalam tiga bagian. Pertama, identifikasi respons awal pemerintah Australia dalam memandang fenomena COVID-19. Kedua, penguraian mengenai langkah-langkah strategis yang diterapkan pemerintah Australia. Ketiga, analisis terhadap respons pemerintah dan dampaknya terhadap perkembangan kasus COVID-19 di Australia.

$\overline{1 \text { Kasus COVID-19 }}$ di Australia mengalami lonjakan di pertengahan bulan Juni, terutama di negara bagian Victoria. Per tanggal 21 Juni terdapat lonjakan angka di Australia yang dalam kurun waktu 7 hari sebanyak 116 kasus baru tercatat di Victoria. Setelahnya, kasus positif di Australia terus mengalami peningkatan. Hingga ditulisnya artikel ini di bulan Agustus, Australia masih berjuang untuk kembali menekan angka persebaran COVID-19.

2 Untuk kemudahan pembagian kurun waktu, data yang digunakan di artikel ini dimulai dari 25 Januari hingga 30 Juni 2020. 


\section{Penutupan Perbatasan sebagai Respon Awal}

Respons awal sebuah negara dalam memitigasi risiko menentukan efektivitas pengelolaan kebijakan selama pandemi berlangsung. Menurut laporan Grattan Institute (Duckett et al. 2020), tiga sektor berisiko yang perlu dikelola oleh pemerintah di kala pandemi adalah kesehatan masyarakat, sistem kesehatan nasional dan keberlangsungan ekonomi negara. Strategi yang diterapkan oleh pemerintah Australia juga ditujukan untuk meminimalkan kerugian akibat pandemi di tiga sektor tersebut. Menurut beberapa analis, salah satu keputusan paling tepat yang dibuat oleh pemerintah Australia adalah tidak menunda untuk menutup perbatasan internasional, terutama dari episentrum virus seperti China di awal pandemi (Duckett dan Stobart 2020; Duckett et al., 2020). Keputusan ini didukung dengan kondisi geografis Australia yang tidak memiliki perbatasan secara langsung dengan negara lain memudahkan Australia untuk 'mengisolasi diri' dari penularan virus COVID-19 (Wyeth 2020; O'Sullivan, et.al 2020)its impact on people and the economy and policy responses to these impacts. It discusses the implications of these responses for postpandemic recovery, though noting that the country's response to the coronavirus disease 2019 (COVID-19.

Australia mencatat kasus pertamanya pada 25 Januari, yaitu seorang pria berusia 5oan di Melbourne yang berasal dari Wuhan. Tidak lama setelahnya, negara bagian lain seperti Queensland dan South Australia juga mengidentifikasi kemunculan virus di wilayah mereka dari pasien yang baru kembali dari luar negeri. Menurut laporan resmi yang dikeluarkan oleh Departemen Kesehatan Australia, 59.8\% dari total keseluruhan kasus bersumber dari luar negeri melalui penduduk yang kembali ke Australia dan membawa atau menularkan virus COVID-19 (Department of Health 2020a). Oleh karenanya, respon awal pemerintah Australia berfokus pada pencegahan masuknya virus COVID-19 dari negara lain.

Salah satu upaya untuk menanggulangi persebaran virus dilakukan Australia dengan membatasi kedatangan penduduk dari China serta penerapan karantina yang ketat. Hal ini dikarenakan China merupakan negara dengan jumlah kasus tertinggi sehingga langkah preventif harus diambil. Pertama, ditemukannya kaitan antara kasus pertama dengan outbreak di Wuhan membuat 
Departemen Luar Negeri dan Perdagangan (DFAT) meningkatkan status Kota Wuhan dan Hubei ke tingkatan 4-do not travel di situs smartraveller (Hunt 2020a). Kedua, pemerintah Australia memberikan bantuan konsuler dan mengevakuasi kepada warga negara Australia dan penduduk tetap (permanent resident) yang terjebak di Wuhan dan Hubei. Namun, saat kembali mereka harus menjalani 14 hari karantina di Christmas Island yang terletak $1500 \mathrm{~km}$ dari daratan utama Australia (Morrison 2020a). Ketiga, dan yang paling krusial, per 1 Februari 2020, Australia menghentikan penerbangan dari dan ke China (Morrison 2020b). Seperti kasus Wuhan dan Hubei, pengecualian diberikan kepada Warga Negara Australia, penduduk tetap, dan anggota keluarga dengan syarat harus melalui karantina mandiri selama 14 hari setelah kedatangan.

Keputusan pemerintah Australia ini mendapat respon yang beragam. Reaksi negatif datang dari pihak pemerintah China dan mahasiswa China yang menempuh pendidikan di Australia. Mereka menganggap keputusan pemerintah Australia terlalu terburu-buru dan berdampak buruk bagi kelanjutan studi mereka (Gillezeau 2020). Di sisi lain pemberitaan yang masif di media tentang kondisi di China membuat masyarakat Australia semakin gelisah dan menuntut pemerintah untuk bertindak tegas. Awalnya Perdana Menteri Scott Morrison mengumumkan pembatasan ini akan berlaku selama 14 hari dan akan dikaji menyesuaikan dengan perkembangan kasus di China. Namun, melihat kondisi yang tak kunjung membaik, keputusan ini terus diberlakukan hingga kini.

Lebih lanjut, virus COVID-19 menyebar sangat cepat dan memunculkan episentrum baru di luar China. Jika dibandingkan dengan negara lain, pada bulan Februari penularan virus COVID-19 masuk dalam kategori minim. Selain itu mayoritas kasus masih terkait dengan luar negeri, misalnya warga negara Australia yang berada di kapal pesiar Diamond Princess di Jepang (Morrison 2020c). Pada periode ini belum teridentifikasi kasus transmisi lokal. Meski demikian, pemerintah Australia merilis rencana keadaan darurat atau Health Sector Emergency Response Plan for COVID-19 pada 18 Februari sebagai respon awal terhadap virus COVID-19. Isi dari dokumen ini adalah langkah yang akan diambil oleh pemerintah Australia dalam menangani persebaran 
COVID-19, utamanya dalam mengantisipasi penularan di tingkat lokal (Department of Health 2020b). Sesuai perkiraan, perlahan kasus di Australia mengalami peningkatan hingga akhirnya pada 1 Maret, pemerintah Australia melaporkan kasus kematian pertama akibat COVID-19. Selang sehari setelahnya, kasus transmisi lokal pertama terdeteksi di New South Wales. Sejak saat ini, pemerintah Australia meningkatkan tingkatan kebijakan dengan mengaktifkan respon keadaan darurat yang sebelumnya telah dipersiapkan.

Pernyataan WHO bahwa virus COVID-19 resmi menjadi pandemi global menambah urgensi bagi pemerintah Australia untuk meningkatkan upayanya dalam menekan laju persebaran virus di dalam negeri. Menurut Menteri Kesehatan Australia, Greg Hunt MP, dua target utama pemerintah Australia saat itu adalah memperlambat laju persebaran virus dan memastikan bahwa sistem kesehatan Australia siap dalam menghadapi lonjakan kasus (Worthington 2020). Sebagai implementasi komitmen tersebut, pemerintah Australia menambah daftar negara yang dilarang masuk seperti Iran (29 Februari), Korea Selatan (5 Maret), dan Italia (11 Maret) mengingat ketiga negara ini saat itu merupakan episentrum persebaran virus COVID-19. Di sisi lain, kasus COVID-19 di Australia berkembang sangat pesat selama bulan Maret. Merujuk pada grafik di bawah, terhitung sejak 13 Maret, per tiga hari kasus positif di Australia bertambah dua kali lebih banyak, dari 200 menjadi 2,00o kasus dalam 12 hari (Ting dan Palmer 2020). 
Australia Government Response to COVID-19:

Coordination and the Effectivity of Policy

\section{Grafik 1}

100 hari perkembangan COVID-19 di Australia (hingga 25

Maret 2020)

\section{Total confirmed COVID-19 cases}

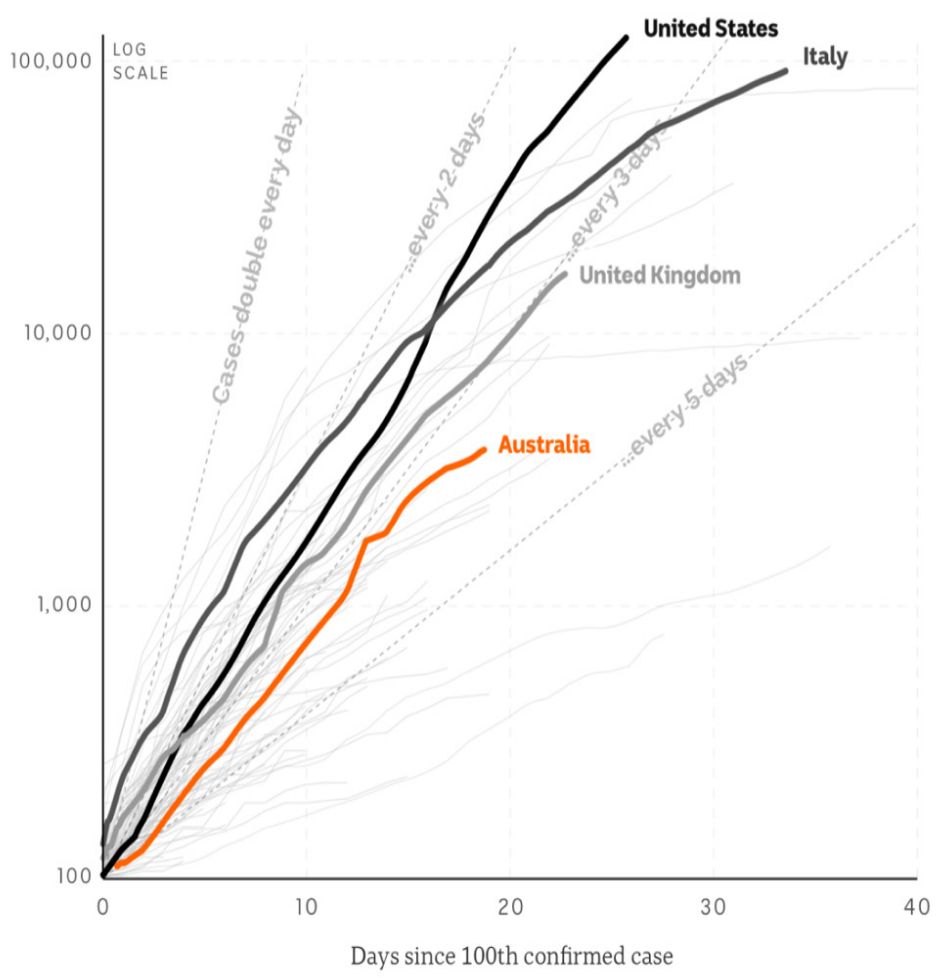

Sumber: Ting dan Palmer (2020)

Secara umum, dapat dikatakan pemerintah Australia cukup sigap dalam merespons perkembangan awal virus COVID-19. Tindakan antisipasi sedari dini melalui rencana keadaan darurat menunjukkan bahwa pemerintah Australia memperhitungkan berbagai skenario yang mungkin terjadi. Namun antisipasi saja tidak cukup, dan dibutuhkan langkah strategis untuk mencegah terjadinya skenario terburuk akibat pandemi. 


\section{Langkah Strategis Australia: Koordinasi Terpusat dan Expert-based Policy}

Pandemi menyebabkan masyarakat mengalami berbagi ketidakpastian. Tidak hanya mengenai kesehatan mereka tetapi juga perekonomian dan kehidupan mereka secara umum. Oleh karenanya, penting bagi pemerintah untuk menyediakan jaminan bagi masyarakat dan memberikan informasi mengenai kondisi terbaru. Belajar dari pandemi influenza di tahun 2009, salah satu hal yang dibutuhkan oleh masyarakat di saat pandemi adalah informasi yang jelas mengenai hal-hal yang perlu dilakukan untuk menghindari penularan virus dan jika memerlukan perawatan lebih lanjut akibat virus (Abraham 2011). Merujuk pada temuan tersebut, cara komunikasi pemerintah sangat berpengaruh pada tingkat kepercayaan publik di tengah pandemi. Masih menurut penelitian yang sama, apabila kompetensi pemerintah dalam menanggapi krisis meragukan, maka tingkat kepercayaan publik juga semakin rendah (Abraham 2011). Apabila kondisi tersebut terjadi, akan sulit bagi pemerintah untuk membuat masyarakat menaati instruksi yang dikeluarkan. Dalam konteks pandemi COVID-19, pemerintah Australia juga awalnya mengalami kesulitan dalam berkomunikasi dengan publik. Namun perlahan tapi pasti, seiring dengan kebijakan yang semakin konkret, kepercayaan publik juga semakin tinggi.

Hasil survei yang dilakukan oleh The Guardian pada awal Maret tentang pemahaman masyarakat Australia terhadap persebaran COVID-19 menunjukkan angka yang cukup mengkhawatirkan. Sebanyak $43 \%$ total responden mengatakan risiko mereka untuk terjangkit COVID-19 cukup kecil (somewhat unlikely) (Lewis 2020). Hal lain yang mengkhawatirkan dari survei tersebut adalah mayoritas yang beranggapan seperti itu adalah kelompok penduduk berusia 55 tahun ke atas, atau dalam kata lain kelompok paling rentan tertular virus COVID-19. Melihat pola pikir yang cukup acuh tersebut, ada kemungkinan penduduk Australia lengah dan hirau terhadap protokol kesehatan yang harus dijalankan untuk memperlambat persebaran virus. Namun di sisi lain, sikap dan pernyataan pemerintah Australia yang kerap berubah di awal pandemi turut berkontribusi terhadap persepsi publik. Banyak pengamat yang mengkritik ketidaktegasan pemerintah Australia 
dalam menjelaskan aturan terkait penutupan sekolah (Blakkarly 2020), batasan perkumpulan publik (Canberra Times 2020), hingga pelanggaran izin kapal pesiar Ruby Princess (Zhou 2020).

Salah satu akar permasalahan dari simpang siur informasi yang terjadi adalah struktur politik yang berlaku di Australia. Sebagai negara yang menganut sistem federal parlementer, terdapat pembagian otoritas antara federal dan negara bagian dalam tata kelola negara. Misalnya di bidang pendidikan, masingmasing negara bagian mengatur sendiri operasional sekolah dan metode penyampaian belajar yang berlaku di yurisdiksi mereka, sedangkan pemerintah federal lebih mengatur dana pendidikan dan kebijakan nasional (Department of Education, Skills, and Employment 2020). Dalam konteks pandemi COVID-19, awalnya seluruh kebijakan ada di bawah otoritas pemerintah federal. Namun seiring dengan meningkatnya jumlah kasus, pemerintah Australia menyadari kebutuhan untuk berkoordinasi dengan pemerintah negara bagian. Sehingga kemudian pada tanggal 13 Maret dibentuk Kabinet Nasional ${ }^{3}$ yang terdiri dari Perdana Menteri dan Kepala Negara Bagian (Premier/Chief Minister). Dalam proses perumusan kebijakan, Kabinet Nasional akan dibantu oleh Australian Health Protection Principal Committee (AHPPC) yang terdiri dari Kepala Staf Medis nasional dan Kepala Staf Medis masing-masing negara bagian (Morrison 2020d). Kabinet inilah yang akan bertanggung jawab terhadap koordinasi strategi penanggulangan virus COVID-19 di Australia.

Lebih lanjut, seperti yang telah disebutkan sebelumnya, bulan Maret adalah periode di mana Australia mengalami lonjakan kasus yang cukup signifikan. Tercatat di akhir bulan Maret terdapat lebih dari 5,00o kasus di seluruh bagian Australia. Sebagai respon terhadap eskalasi kasus, pemerintah Australia melalui Kabinet Nasional memutuskan untuk menerapkan aturan yang lebih tegas. Salah satunya adalah keputusan untuk menutup perbatasan untuk semua negara atau dalam kata lain seluruh orang asing yang bukan warga negara atau penduduk tetap tidak dapat masuk ke Australia sejak tanggal 20 Maret 2020 (Morrison 2020e). Untuk pertama kalinya dalam sejarah, Australia resmi menutup diri.

3 Kabinet Nasional dibentuk untuk menggantikan posisi forum antarpemerintahan yang sebelumnya disebut Council of Australian Government (COAG). Info lebih lanjut: https://www.coag.gov.au 
Selain koordinasi yang terpusat, Kabinet Nasional juga merupakan bentuk upaya pemerintah Australia dalam menyusun kebijakan berdasar saran ahli. Di sektor kesehatan, seluruh kebijakan yang dikeluarkan pemerintah merujuk pada modelling scenarios yang dibuat oleh pakar epidemiologi Australia. Dari hasil modelling scenarios tersebut, untuk meminimalkan risiko beban yang harus ditanggung sistem kesehatan, pemerintah dan masyarakat Australia harus melakukan tiga hal: (1) melakukan physical distancing, (2) meningkatkan kapasitas sistem kesehatan, dan (3) melakukan isolasi bagi pasien terjangkit virus dan orang terdekatnya (Department of Health 2020c). Oleh karenanya, pemerintah Australia mulai menetapkan aturan lockdown penuh di seluruh negara bagian di mana penduduk Australia hanya boleh melakukan kegiatan esensial seperti belanja bahan pokok, berolahraga, dan bekerja atau sekolah jika tidak memungkinkan untuk dilakukan dari rumah (Morrison 2020f). Setelah keputusan ini keluar, masing-masing negara bagian juga mulai menutup perbatasan mereka guna mengontrol persebaran virus melalui transmisi lokal antarindividu. Sejak saat itu, penduduk Australia resmi menjalani kesehariannya di tengah total lockdown.

Lebih lanjut, selain mencegah penularan virus melalui physical and social distancing, pemerintah Australia juga meningkatkan jumlah tes yang dilakukan setiap harinya. Terhitung sebanyak 2, 455,982 tes telah dilakukan sejak Januari hingga Juni 2020 dengan persentase kasus positif sebanyak 0.3\% (Department of Health 2020a). Tidak hanya itu, masing-masing negara bagian juga turut bergerak dengan menyediakan drive through testing bagi masyarakat Australia yang merasa memiliki gejala COVID-19. Contohnya di Australian Capital Territory (ACT), ketika kasus keempat teridentifikasi di ACT, pemerintah setempat langsung mendirikan lokasi tes drive through guna mengurangi jumlah penduduk yang berkunjung ke rumah sakit sekaligus untuk meminimalkan risiko penularan kepada pasien yang rentan (Burnside 2020). Pemerintah federal dan negara bagian juga secara berkala mengevaluasi kriteria kelayakan untuk melakukan tes. Awalnya hanya individu yang termasuk dalam kategori rentan, seperti baru kembali dari luar negeri atau pernah kontak dengan pasien positif, yang boleh melakukan tes COVID-19. Namun kini semua yang menunjukkan gejala COVID-19 juga disarankan untuk 
melakukan tes sejak dini. Tidak hanya itu, pemerintah Australia juga giat melakukan contact tracing sebagai bentuk upaya mencegah persebaran virus yang lebih luas. Salah satu bentuk dari inisiatif ini adalah diluncurkannya aplikasi COVIDSafe (Hunt 2020b), walaupun pada akhirnya penggunaan aplikasi ini tidak memenuhi target karena masyarakat yang skeptis dengan keamanan privasi yang disediakan aplikasi tersebut

Untuk mengimbangi upaya pencegahan persebaran virus di antarindividu, pemerintah Australia juga meningkatkan upaya perlindungan terhadap sistem kesehatan nasional. Selain yang tercantum dalam rencana keadaan darurat yang dirilis di bulan Februari, pemerintah Australia juga memberikan dana bantuan sebesar \$1.1 Triliun untuk membantu fasilitas kesehatan tingkat pertama (Desborough et al. 2020). Salah satu bentuk implementasi dari bantuan dana ini adalah peningkatan fasilitas telehealth di mana melalui fasilitas ini publik dapat berkonsultasi dengan dokter atau tenaga kesehatan secara jarak jauh, seperti telepon atau panggilan video. Tujuan dari pemanfaatan fasilitas ini adalah untuk melindungi tenaga kesehatan dari risiko terpapar virus (Hunt 2020c).

Seperti halnya banyak negara lain, sektor perekonomian Australia juga terpukul karena pandemi COVID-19. Oleh karenanya, pemerintah Australia membentuk National COVID19 Coordination Commission yang terdiri dari tokoh bisnis dan organisasinon-profit sebagai wadah untuk perumusan kebijakan di sektor sosio-ekonomi (Morrison 2020g). Salah satu kebijakan dari komisi ini adalah diluncurkannya berbagai subsidi sosial seperti JobSeeker dan JobKeeper, aturan moratorium penggusuran bagi individu yang tidak bisa memenuhi kewajiban membayar sewa tinggal, dan kebijakan lain yang berfungsi sebagai social safety net bagi warga negara Australia. Menurut Financial Review, per bulan Mei 2020 pemerintah Australia memberi bantuan stimulus fiskal sebesar 10.6\% dari total GDP atau sekitar \$214 triliun (Cranston 2020). Jumlah ini merupakan salah satu yang terbesar di dunia selain Amerika Serikat dan Kanada.

Berbagai kebijakan yang telah disebutkan sebelumnya menunjukkan upaya serius pemerintah Australia untuk meminimalkan kerugian yang dialami akibat pandemi COVID-19. 
Kerugian yang dimaksud di sini tidak hanya mengenai kerugian yang berbentuk materi, namun juga keselamatan nyawa penduduk dan sistem kesehatan nasional. Kolaborasi berbagai kebijakan dan komitmen semua pihak dalam menekan laju persebaran virus membuahkan hasil ketika kurva epidemiologi COVID-19 di Australia mulai melandai di bulan April.

\section{Peran Komitmen Kolektif Pemerintah dan Masyarakat saat Pandemi}

Setelah lebih dari satu bulan menerapkan protokol kesehatan berupa karantina, isolasi dan social distancing yang ketat, kondisi persebaran virus di Australia menunjukkan tren positif di bulan April. Melihat kurva yang mulai melandai, pada awal Mei Perdana Menteri Scott Morrison mengumumkan rencana pemerintah untuk melakukan relaksasi lockdown (Morrison 2020h). Terdapat tiga tahapan yang disediakan sebagai rujukan untuk kemudian disesuaikan dengan kondisi di masing-masing negara bagian, dengan tahap ketiga yang paling mendekati situasi normal sebelum pandemi. ${ }^{4}$

Melihat kesuksesan Australia dalam melandaikan kurva persebaran virus COVID-19, dapat dilihat bahwa kebijakan yang diterapkan oleh pemerintah Australia tidak hanya reaktif tetapi juga proaktif. Hal ini dapat dilihat dari keputusan untuk menutup perbatasan internasional di awal pandemi. Walaupun beberapa pengamat menganggap bahwa pemerintah Australia cukup lambat untuk menutup perbatasan dengan negara lain di luar China (Duckett dan Stobart 2020), kebijakan tersebut terbukti efektif menekan laju persebaran COVID-19 di Australia. Berdasar hasil penelitian yang dilakukan oleh Costantino et.al (2020), pembatasan perjalanan dari China terbukti mampu mengurangi sekitar $87 \%$ risiko penularan virus di Australia. Hasil serupa juga didapatkan dari penelitian Adekunle et al., (2020) yang menyatakan bahwa keputusan tersebut mampu menyebabkan persebaran virus yang masif selama kurang lebih 4 minggu lebih lambat di Australia.

4 Saat ditulisnya artikel ini di bulan Agustus, beberapa negara bagian seperti ACT dan Western Australia sudah berada di tingkat ketiga lockdown relaxation dan kehidupan penduduk mulai berangsur normal walaupun dengan protokol kesehatan yang ketat. 
Namun sayangnya, di sisi lain pemerintah Australia melakukan kesalahan dalam keputusan untuk menutup perbatasan, salah satunya dengan memberikan ijin bersandar kapal pesiar Diamond Princess dan Ruby Princess. Seperti yang disebutkan secara singkat di bagian sebelumnya, banyak warga negara Australia yang masuk dalam daftar penumpang kapal pesiar yang juga hotspot virus COVID-19. Menurut data yang didapat oleh Ting dan Palmer (2020), 10\% dari total kasus di Australia sampai bulan April adalah pasien yang juga penumpang kedua kapal pesiar tersebut. Dengan kata lain, apabila kapal tidak diizinkan bersandar, ada kemungkinan angka persebaran virus di Australia menjadi jauh lebih rendah dari yang ada. Saat ini kasus Ruby Princess sedang dalam proses investigasi untuk ditelusuri apa/siapa penyebab lengahnya pengawasan pemerintah dalam memberikan ijin tersebut. Dari kedua contoh tersebut, dapat dilihat bahwa saat pandemi, nyawa penduduk harus menjadi prioritas utama dalam proses perumusan kebijakan.

Di sisi lain, kesuksesan Australia juga disebabkan oleh alur penanganan yang jelas sehingga membuat masyarakat percaya atas kapabilitas pemerintah dalam menangani krisis. Keputusan untuk membentuk Kabinet Nasional sebagai wadah koordinasi pemerintah federal dan negara bagian, ditambah dengan konsultasi dengan para ahli menunjukkan bahwa pemerintah Australia serius untuk menangani pandemi COVID-19. Namun, satu hal yang kemudian menjadi faktor pendukung kesuksesan Australia adalah kepatuhan masyarakat terhadap protokol kesehatan yang diterapkan pemerintah. Kepatuhan ini tidak didapat begitu saja namun merupakan dampak dari kepercayaan publik terhadap kapabilitas pemerintah. Menurut laporan yang dilakukan oleh Democracy 2025 initiative, sebuah kolaborasi riset antara Museum of Australian Democracy dan TrustGov Project di University of Southampton, kepercayaan publik Australia kepada pemerintah lebih tinggi dibandingkan Amerika Serikat, Italia dan Inggris (Evans et.al 2020). Dalam laporan tersebut, tertulis bahwa terdapat peningkatan signifikan atas kepercayaan public kepada pemerintah federal dari $29 \%$ menjadi $54 \%$. Selain itu, hasil survei membuktikan bahwa mayoritas penduduk Australia patuh terhadap aturan yang diterapkan oleh pemerintah dalam menanggulangi virus COVID-19. Dengan kata lain, ada komitmen 
kolektif yang terjalin antara pemerintah dan masyarakat yang akhirnya membuat kebijakan menjadi efektif.

Secara keseluruhan dapat disimpulkan bahwa di tengah kondisi krisis diperlukan intervensi dari pemerintah untuk mengelola berbagai sektor kenegaraan. Mengingat bahwa persebaran virus COVID-19 terjadi dengan sangat cepat, pemerintah harus berani membuat keputusan tegas guna menyelamatkan kestabilan negara. Di sisi lain, peran masyarakat juga tidak kalah pentingnya. Kepatuhan masyarakat dalam menjalankan aturan physical/social distancing menjadi sangat krusial dalam keberhasilan negara di tengah pandemi. Mengingat bahwa hingga saat ini vaksin masih belum ditemukan, kerjasama antara pemerintah dan masyarakat merupakan cara terbaik untuk meminimalkan persebaran virus COVID-19.

\section{Referensi}

\section{Jurnal dan Jurnal Daring}

Abraham, Thomas, 2011. "Lessons From The Andemic: The Need For New Tools For Risk And Outbreak Communication", Emerging Health Threats Journal, 4(1), p. 1-4. doi: 10.3402/ehtj.v4io.7160.

Adekunle, Adeshina. et al, 2020. "Delaying The COVID-19 Epidemic In Australia: Evaluating The Effectiveness Of International Travel Bans", Australian and New Zealand Journal of Public Health, 44(4), pp. 257-259. doi: 10.1111/1753-6405.13016.

Costantino, Valentina, et.al, 2020. 'The Effectiveness Of Full And Partial Travel Bans Against COVID-19 Spread In Australia For Travellers From China During And After The Epidemic Peak In China', Journal of Travel Medicine, pp. 1-7. doi: 10.1093/jtm/taaao81.

Desborough, Jane. et al., 2020. "Australia's National COVID-19 Primary Care Response", Medical Journal of Australia, 213(3), pp. 104-106. doi: 10.5694/mja2.50693. 
Australia Government Response to COVID-19:

Coordination and the Effectivity of Policy

O'Sullivan, Dominic. et.al., 2020. 'The Impact and Implications of COVID-19: An Australian Perspective', The International Journal of Community and Social Development, 2(2), pp. 134-151. doi: 10.1177/2516602620937922.

\section{Artikel Daring}

Blakkarly, Jarni, 2020. "Teachers and Parents Slam Mixed Messages Over School Closures Across Australia” [daring]. In https://www.sbs.com.au/news/teachers-and-parentsslam-mixed-messages-over-school-closures-acrossaustralia [accessed 15 August 2020]

Burnside, Niki, 2020. "Drive-Through COVID-19 Testing Opens in the ACT as Fourth Coronavirus Case Confirmed, Coles Ram Raid Not Related to Panic Buying" [daring]. In https:// www.abc.net.au/news/2020-03-19/fourth-case-anddrive-through-testing-announced/12070930 [accessed 15 August 2020]

Cranston, Matthew, 2020. "Australia's Rescue Package The World's Biggest, Bar One", [daring]. In https://www.afr. com/policy/economy/australia-s-rescue-package-theworld-s-biggest-bar-one-20200506-p54qdc [accessed 15 August 2020]

Duckett, Stephen, et.al, 2020. "Coming out of COVID-19 lockdown: the next steps for Australian health care”. [daring] https:// grattan.edu.au/wp-content/uploads/2020/06/Comingout-of-COVID-lockdown-the-next-steps-for-Australianhealth-care.pdf [accessed 1 August 2020]

Duckett, Stephen, and Anika Stobart, 2020. “4 Ways Australia’s Coronavirus Response Was A Triumph, and 4 Ways It Fell Short” [daring]. In https://theconversation.com/4ways-australias-coronavirus-response-was-a-triumphand-4-ways-it-fell-short-139845 [accessed 15 August 2020].

Gillezeau, Natasha, 2020. “China Says Australia’s Travel Ban No 
Good For Either Side" [daring]. In https://www.afr.com/ policy/foreign-affairs/china-says-australia-s-travel-banno-good-for-either-side-20200311-p548z5 [accessed 14 August 2020]

Lewis, Peter, 2020. "Faced with coronavirus and a trust deficit, can Scott Morrison swallow his pride?"[daring] in https://www. theguardian.com/australia-news/commentisfree/2020/ mar/11/faced-with-coronavirus-and-a-trust-deficit-canscott-morrison-swallow-his-pride

The Canberra Times, 2020. "Mixed Messages on Coronavirus Mass Gatherings" [daring]. https://www.canberratimes.com. au/story/6677991/mixed-messages-on-mass-gatherings/ [accessed 15 August 2020]

Ting, Inga and Alex Palmer, 2020. "One Hundred Days of The Coronavirus Crisis' [daring]. In https://www.abc. net.au/news/2020-05-04/charting-100-days-of-thecoronavirus-crisis-in-australia/12197884?nw $=0$ [accessed 9 August 2020]

Worthington, Brett, 2020. "Coronavirus Pandemic Fears Prompt Government To Activate Emergency Response And Extend Travel Ban" [daring]. In https://www.abc.net. au/news/2020-02-27/federal-government-coronaviruspandemic-emergency-plan/12005734 [accessed 14 August 2020]

Wyeth,Grant,2020."HowWellHasAustraliaManagedCOVID-19?", [daring]. In https://thediplomat.com/2020/04/how-wellhas-australia-managed-covid-19/. [accessed 15 July 2020]

Zhou, Naaman, 2020. "Anatomy of a coronavirus disaster: how 2,700 people were let off the Ruby Princess cruise ship by mistake", [daring] in https://www.theguardian.com/ world $/ 2020 / \mathrm{mar} / 24 /$ anatomy-of-a-coronavirus-disasterhow-2700-people-were-let-off-the-ruby-princess-cruiseship-by-mistake [accessed 15 August 2020] 
Australia Government Response to COVID-19:

Coordination and the Effectivity of Policy

\section{Dokumen dan Publikasi Resmi}

Department of Education, Skills, and Employment. "How Are Schools Funded in Australia?" [daring] in https://www. education.gov.au/how-are-schools-funded-australia [accessed 14 August 2020]

Department of Health, 2020a. "Coronavirus (COVID-19) at a glance - 30 June 2020" [daring]. in https://www. health.gov.au/sites/default/files/documents/2020/o6/ coronavirus-covid-19-at-a-glance-30-june-2020.pdf [accessed 13 August 2020]

2020b. "Australian Health Sector Emergency Response Plan for Novel Coronavirus (COVID-19)" [daring]. in https://www.health.gov.au/ sites/default/files/documents/2020/02/australianhealth-sector-emergency-response-plan-for-novelcoronavirus-covid-19_2.pdf [accessed 13 August 2020]

, 2020c. "Government response to the COVID-19 outbreak", [daring]. in https://www.health. gov.au/news/health-alerts/novel-coronavirus-2019ncov-health-alert/government-response-to-the-covid-19outbreak [accessed 13 August 2020]

Hunt, Greg, 2020a. "First confirmed case of novel coronavirus in Australia", [daring] in https://www.health.gov.au/ ministers/the-hon-greg-hunt-mp/media/first-confirmedcase-of-novel-coronavirus-in-australia [accessed 1 August 2020]

, 2020b. "COVIDSafe: New app to slow the spread of the coronavirus" [daring] in https://www.health.gov.au/ ministers/the-hon-greg-hunt-mp/media/covidsafe-newapp-to-slow-the-spread-of-the-coronavirus [accessed 16 August 2020]

, 2020c. "Australians Embrace Telehealth To Save Lives During COVID-19" [daring] in https://www. 
health.gov.au/ministers/the-hon-greg-hunt-mp/media/ australians-embrace-telehealth-to-save-lives-duringcovid-19 [accessed 15 August 2020]

Morrison, Scott, 2020a. "Assisted Departure And Strict Quarantine For Australians From Wuhan/Hubei” [daring]. in https:// www.pm.gov.au/media/assisted-departure-and-strictquarantine-australians-wuhanhubei [accessed 12 August 2020]

, 2020b. "Updated Travel Advice To Protect Australians From The Novel Coronavirus" [daring]. in https://www.pm.gov.au/media/updated-travel-adviceprotect-australians-novel-coronavirus [accessed 12 August 2020]

Vic" [daring] https://www.pm.gov.au/media/pressconference-melbourne-vic-o [accessed 13 August 2020]

, 2020d. "Advice on Coronavirus" [daring] in https://www.pm.gov.au/media/advice-coronavirus [accessed 14 August 2020]

, 2020e. "Border Restriction" [daring] in https:// www.pm.gov.au/media/border-restrictions [accessed 14 August 2-020]

, 2020f. "Update on Coronavirus Measures" [daring] in https://www.pm.gov.au/media/updatecoronavirus-measures-24-March-2020 [accessed 15 August 2020].

, 2020g. "National COVID-19 Coordination Commission" [daring] in https://www.pm.gov.au/media/ national-covid-19-coordination-commission [accessed 13 August 2020]

2020h. "Update on Coronavirus Measures" [daring] in https://www.pm.gov.au/media/updatecoronavirus-measures-08may20 [accessed 15 August 2020]. 
Australia Government Response to COVID-19:

Coordination and the Effectivity of Policy 